\title{
Academician perceptions towards online student evaluation
}

\author{
Nor Hapiza Mohd Ariffin ${ }^{1}$, Siti Nor Hidayah Askol ${ }^{2}$ \\ ${ }^{1}$ Faculty of Computer Science and Mathematics, University Technology Mara, Malaysia \\ ${ }^{2}$ CLL Systems Sdn Bhd, Petaling Jaya, Selangor, Malaysia
}

\begin{tabular}{l}
\hline \hline Article Info \\
\hline Article history: \\
Received Jan 20, 2019 \\
Revised Apr 17, 2019 \\
Accepted May 21, 2019 \\
\hline
\end{tabular}

\section{Keywords:}

Academicians'perception

Formative assessment

Higher education

Student evaluation

Summative assessment

\begin{abstract}
In higher education institutions, student evaluation is important to ensure that students are given the opportunity to attain a high quality of education. In Universiti Teknologi Mara (UiTM) Malaysia, student evaluation was implemented through a system called Student Feedback Online (SuFO). This study aims to investigate and analyze the perception of academicians towards the usage of online student evaluation using SUFO in UiTM. The research employed the quantitative analysis and supported by Rasch measurement. The respondents are academicians in UiTM Shah Alam. A total of 152 academicians responded to the questionnaires. By using a Likert scale, 25 items were designed in the questionnaire and distributed by official email to the academicians. Data were analyzed using Rasch measurement to measure the validity and reliability of the items and the respondents involved in this research, while SPSS was used to analyze the quantitative data. The results showed that the academicians accepted the outcome value of student evaluation and they agreed that results of student evaluation should be used for formative assessment. It is recommended for future research, an instrument using a method of multi-dimensional evaluation of teaching should be developed to evaluate the effectiveness of university teaching.
\end{abstract}

Copyright $\odot 2019$ Institute of Advanced Engineering and Science. All rights reserved.

\section{Corresponding Author:}

Nor Hapiza Mohd Ariffin,

Faculty of Computer and Mathematical Sciences,

Universiti Teknologi Mara, Malaysia.

Email: hapiza@tmsk.uitm.edu.my

\section{INTRODUCTION}

Students evaluation has become an important practice in many institutions around the world. In some institutions, students are often requested to complete different kinds of surveys which depict their opinion about their educational experiences, the performance of teaching staff, specific aspects of their institutions such as the facilities, infrastructures and their courses. In this sense, students are seen as information providers. According to [1], students are the education stakeholders. Therefore, it is important for the students to evaluate the academicians since students are part of an educational institution. Thus, the evaluation outcome will use to improve the quality of teaching effectiveness in the classroom as well as for administrative purposes.

As stated by [2], if student's evaluation is conducted in the right manner, it can yield potential benefits to many stakeholders in the higher education context. This statement was also supported by [3] who mentioned that students' evaluation is an effort to enhance teaching and learning environment in higher level education context. However, some problem occured such as there were academicians doubt about the evaluation made by the student towards the performance of the academicians in teaching and their professional growth because of some biases due to gender types or lacking of faculty facilities [4]. This is being supported by the previous research done by [2] which discovered that the academicians have a negative perception on the honesty of student evaluation. On the other hand, the elements regarding the punctuality, 
transparency, self-reflection and relationship between the academicians and students were positively rated based on the study that being made by [5]. While there is some debate among academicians about student evaluation, it has been accepted that student evaluation is vital for measuring teaching effectiveness because the results can be used for major decisions about the institutional future in academia. There are two types of decisions which are formative and summative [6]. Formative purpose is defined by [1] which refers to the results of student evaluation used as tools to make an improvement in teaching effectiveness and to improve the student learning environment either in the classroom or outside the classroom.

For the summative purpose, in general, [7] define the summative purpose as the feedback mechanism which is used for personnel and administrative decision. In addition, [8] gives more specific definition of summative purpose. It is referring to student evaluation that is used for administrative or personnel decision such as promotion, salary increment, demotion, dismissal, awards and meeting public or government accountability demands. Undeniably, these decisions have an impact on the quality of the institutions and created a problem. Hence, there is some argument about adopting of student evaluation as a source of evidence for measuring institution effectiveness whether for formative or summative purposes or both. [9] mentioned that the results of student evaluation can be used for formative and summative purposes which gives no significant difference between them based on the academician's perspective. On the other hand, [1] found that there is a significant difference in the academicians' perception of student's evaluation when it is a means of formative and summative purposes.

As a conclusion, student evaluation is one of the important things in ensuring that the educational institutions can produce a good product by having a high quality and competence of the academicians. Students as one of the stakeholders in educational institutions can provide a good value of judgment and are able to contribute in administration decision. For the academicians, the student evaluation can be used for two main purposes which are summative and formative purposes.

Nonetheless, sometimes the result of student evaluation has been misinterpreted since some people lack the understanding of the definition of the formative and summative terms. This was supported by [10] who mentioned about academicians debating on the relationship between formative and summative assessments. Hence, it is not clearly stated how to determine whether they intended to use formative or summative assessment. Therefore, this study is conducted to analyze the academicians' perception on student evaluation using Student Feedback Online (SuFO) among the students and academicians in Universiti Teknologi Mara (UiTM) for formative and summative purposes.

\section{RESEARCH METHOD}

The aims of this research are to investigate the academicians perspective towards the student evaluation that is being implemented in UiTM which is known as SuFO. Student Feedback Online (SuFO) is an online system that was developed for students to evaluate the whole performance of the lecturers or academicians in teaching and learning such as the quality of the academicians, performance, content and is also being used to evaluate the facilities provided.

There are three objectives for this research which are: i) to investigate the academicians' perception on the value of the student evaluation using $\mathrm{SuFO}$, ii) to determine the academicians' perception on $\mathrm{SuFO}$ towards formative assessment and iii) to determine the academician's perception on SuFO towards summative assessment.

The instrument used in this research is "Survey of Academicians' perception on student evaluation using Student Feedback Online (SuFO)". This instrument was adapted from [2] because it was designed to investigate academicians' perception on student evaluation for formative and summative assessment.

In the beginning, the researcher conducted a pilot test and the findings showed the overall reliability is 0.909 . According to [11], the Cronbach Alpha values that were above 0.70 is considered a good reliability, therefore, this instrument could be considered as having good reliability. After the validation and verification, then a questionnaire was distributed to respondents. The research study was carried out using a convenient sampling method. Approximately 200 sets of questionnaires were distributed to academicians in UiTM. About 170 sets of questionnaires distributed in UiTM were returned. However, only 152 of the questionnaires could be used, while the remainder of the sets were unusable. The justification for the "unusable" forms was that most of the question were not answered. Therefore, it was decided that these forms be classified as "unusable".

The responses were measured by using Likert scale. Likert scale is a measurement scale that has a five-response category ranging from "strongly disagree" to "strongly agree", which requires the respondents to indicate the degree of agreement or disagreement to each series of statements in the questionnaire.

The questionnaire was divided into four (4) sections. Section 1 is about demographic information of the respondents, Section 2 is about the value of student's evaluation based on the academician's perspective, 
Section 3 is about the academician's perspective on student's evaluation when it was used for formative purpose and the last section is Section 4 is about the academician's perspective on student evaluation when it was used for summative purpose. Table 1 shows the summary of items that measured on this survey.

Table 1. Items Measured

\begin{tabular}{|c|c|c|}
\hline Items & Number of item & Measures \\
\hline \multirow[t]{5}{*}{ Section 1: Demographic Data } & \multirow[t]{5}{*}{5} & Faculty \\
\hline & & Gender \\
\hline & & Higher level of education \\
\hline & & Teaching experience \\
\hline & & Position of academicians \\
\hline \multirow{10}{*}{$\begin{array}{c}\text { Section 2: } \\
\text { Value of student evaluation }\end{array}$} & \multirow[t]{10}{*}{10} & Idea acceptance \\
\hline & & Student responsibility \\
\hline & & Student judgment \\
\hline & & Lecturers preparation \\
\hline & & Lecturers punctuality \\
\hline & & Transparency of relationship \\
\hline & & Improvement relationship \\
\hline & & Lecturers commitment \\
\hline & & Lecturers innovation \\
\hline & & Lecturers disciplined \\
\hline Section 3: & \multirow[t]{5}{*}{5} & Teaching improvement \\
\hline Formative purpose & & Instruction improvement \\
\hline & & Student's learning improvement \\
\hline & & Professional growth \\
\hline & & Self-evaluation \\
\hline \multirow{5}{*}{$\begin{array}{c}\text { Section 4: } \\
\text { Summative purpose }\end{array}$} & \multirow[t]{5}{*}{5} & Administrative decision \\
\hline & & Lecturers promotion \\
\hline & & Salary increment \\
\hline & & Awards \\
\hline & & Lecturers retention \\
\hline
\end{tabular}

In order to analyze the data, Statistical Packages for Social Science (SPSS) and Rasch Measurement were used. In describing and understanding the data from the questionnaires, descriptive and inferential statistic method are used. Meanwhile, Rasch measurement was used to measure the reliability of each item and every person involved in the research. In other word, the item difficulty and person's ability to answer the questionnaire were measured.

\section{RESULTS AND ANALYSIS}

There are a lot of research regarding human science which is more towards the field of perception. Hence, it is difficult to measure either it is qualitative or quantitative analysis [12]. In conducting any research, the most important thing is to obtain valid data, in order to produce valid output and information to be disseminated to others.

The Rasch measurement model contains an instrument that meets the needs and requirements that are suitable to be adopted in social science research [13]. The main features of Rasch measurement are to measure the validity and reliability of items and person in order to examine the suitability of the item and person in the research [14].

Reliability test and respondents also indicates that the set of questionnaires are valid and reliable to be measured [15]. As stated earlier, Rasch measurement is an instrument that is important in data analysis [16]. Items and persons will be measured while conducting an analysis to measure the validity and reliability of the data to ensure it can be transformed into valid and usable information.

In using Rasch measurement, this research analyzes data of an item and person. This research closely related to qualitative measure and it is good to construct linear measure by using this Rasch measurement. The respondent's faculty, gender, higher level of education, teaching experience and position of the academicians are the data were collected and analyzed. Likert Scale from lowest range of 1-strongly disagree until 5-strongly agree was being used in this research. The analysis was conducted by Rasch Measurement software with student version known as Ministep. It is to identify the validity and reliability of an item and person or participant involved in the analysis. An item is measured based on the level of difficulty of items. On the other hand, validity and reliability of a person is determined by the ability of person involved to answer the item in questionnaires.

Most of the academician's response to the questionnaire were female (52 percent). A majority of the academicians have a higher education of Master's degree (49 percent). For teaching experience, 
purpose. Their research also found that academicians support student evaluation being used for formative purpose

The highest value of mean is 3.70. It is about satisfaction of feedback on student's evaluation is helping lecturers to improve their teaching. According to [5], by calling attention to teaching methods and outcome, student evaluation plays a positive role in improving the condition of teaching and learning. In addition, there were many researchers stated that feedback from student rating can help improve teaching instruction $[19,20]$.

[21] had provided a list of factors about effective teachers. One of the factors is about the teachers will use feedback from students and others to assess and improve their teaching. Based on this statement, the mean value which is 3.61 indicate that academicians in UiTM agreed that student evaluation report will help academicians to evaluate themselves. Other finding with 3.60 mean value showed that academicians agree that result of student evaluation is needed to improve classroom instruction. To summarize the analysis on this section with overall mean value is 3.6 showed that the academicians mostly accept formative assessment for the usage of student's evaluation. In addition, a research done by [1] showed the same finding that academicians in a Nigerian university accept student's evaluation for formative purpose

Analysis for Section 4 contains five items of questions about the summative assessment in student evaluation. Summative purpose is being defined by [8] as the usage of student's evaluation in making administrative and personnel decision such as promotion, salary increment and awards of the academicians. There are several uniqueness in this research findings if compared with other researchers. The first statement that was asked in the questionnaire was about the need of student evaluation in supporting the administrative decision making. It showed that the mean value is 3.24 which justifies the academicians' perceptions in accepting the statement. It is different with research done by [2] which showed that academicians rejected the statement that student evaluation is needed in administrative decision making. [1] identified that one of the benefits in student evaluation is excellence in teaching can be recognized and awarded. In contrast, academicians in UiTM rejected that student evaluation is needed to select the best teaching award in the faculty. It is based on the mean value 2.59 which showed their disagreement towards the above statement.

A little bit lower for mean value 2.54 showed that the academicians reject that student evaluation should be used for promotion of the lecturers although [8] found that the results from student evaluation can be used for academicians' promotion. Nonetheless, this research finding is similar to the research done by [2] that is academicians refuted the idea of student evaluation being used for promotion purposes. The second lowest value of mean in section 4 is about the idea of student evaluation is needed for salary increment for the lecturers. From the analysis, it showed a mean value of 2.39 which can be interpreted as the academicians were rejected the idea. [2] also found that using student evaluation as a reference for salary increment is strongly criticized by the academicians. Academicians in UiTM do not support that student evaluation can be used for decision of retention or dismissal of the academicians. It is being supported with the value of mean 2.72 from the analysis.

The findings from this study can be concluded as academicians in UiTM rejecting the idea to use student evaluation for summative purposes with overall mean value of 2.81 . This conclusion is supported by the overall results on research done by [2]. Apparently, the majority of academicians strongly oppose the idea of using student evaluation for summative assessment [22].

\section{CONCLUSION}

This paper presents about academicians' perception towards online student evaluation using SuFO. Currently, there is some debate about the purpose of student evaluation bring for the benefit of academicians. Therefore, this paper discuss the matter based on the value and purposes of student evaluation either it is being used for formative or summative purpose. As a summary, the overall results of this research indicate that the academicians acknowledge students as evaluators to the academicians in improving teaching skills and effectiveness. However, the academicians prefer to adopt it as formative purposes rather than summative purposes. These findings are also supported by a research from [23] which stated that student evaluation of teaching should not be used for summative assessment of university faculty. Nonetheless, [24] suggested that formative evaluations can be used to complement the summative evaluations at the end of semester evaluations. She further stated that the formative evaluations were quite valuable in that they provide the instructor and other stakeholders with direct feedback during the course, while changes could be made. This study also elicit that the usage of online tools for student evaluation brings more flexible with a very low cost and faster as well as organized compared to the manual system. The benefits from online student evaluation that all the input can be kept efficiently and effectively for future use. With the big data technology, it is hoped that there will be a way to mining the data to get the insightful information. 
It is recommended that student evaluation should have a multidimensional method of teaching evaluation. The academicians can measure the quality of teaching along the years of student learning by determining the result of current semester with previous semester through evaluation indicators. The academicians also can determine the level of quality of themselves for the whole semester.

Furthermore, UiTM apparently needs an accurate instrument to evaluate teaching and the academicians since there are a lot of issues regarding the validity and reliability of students as the evaluator to the academicians. This suggestion was supported by a study from [25]. This instrument should not only make the student as the evaluator but also as a stakeholder of the university in order to evaluate the academicians. Hence, the results from this research can be used as a reference and guideline to make an improvement towards the instrument of student evaluation.

\section{ACKNOWLEDGEMENTS}

Special thanks to academicians from UniversitiTeknologi Mara who involved as respondents and give their feedback for data collection phase

\section{REFERENCES}

[1] S. Aduwa-Ogiegbaen and E. Iyamu, "Using information and communication technology in secondary schools in Nigeria: Problems and prospects." Educational Technology and Society, vol. 8 No 1, pp 104-112, 2005.

[2] S. Machingambi and N.Wadesango, "University lecturers' perceptions of students evaluation of their instructional practices," Anthropologist, vol 13 No 3, pp 167-174, 2011.

[3] S. Moore and N.Kuol, "Students evaluating teachers: Exploring the importance of faculty reaction to feedback on teaching," Teaching in Higher Education, vol 10 No 1, pp 57-73, 2005.

[4] A. Kamalia and M. NorLaila, "Citizen-centric Demand Model for Transformational Government Systems," Proceedings Pacific Asia Conference on Information Systems (PACIS), 2017.

[5] M. Jackson, "Teacher characteristics and teaching effectiveness," Studies in education, vol 12 No 1 , pp 101-112, 1998.

[6] B. Ronald, "Survey of 12 Strategies to Measure Teaching Effectiveness," International Journal of Teaching and Learning in Higher Education, vol 17 No 10, pp 48-62, 2005.

[7] E. Keane and I.Labhrainn, Obtaining student feedback on teaching and course quality. Briefing paper, available at:https://www.researchgate.net/publication/246989890_Obtaining_Student_Feedback_on_Teaching_Course_Qual ity (accessed 1 March 2018).

[8] R.Gold, "Evaluation of instruction," Educational Studies, vol 15 No 1, pp 31-42, 2001.

[9] M. Jackson, "Teacher characteristics and teaching effectiveness," Studies in education, vol 12 No 1, pp 101-112, 1998.

[10] M. Taras, "Assessment-Summative and Formative - Some Theoretical Reflections," British Journal of Educational Studies, vol 53 No 3, pp 466-78, 2005.

[11] C. Dancey and J. Reidy, Statistics Without Maths for Psychology. Harlow, Pearson Education, 2002.

[12] W.M, Wan Nur'ashiqin, "Memprofilkan Guru Bahasa Inggeris Yang Berpotensi Untuk Mendidik Amalan Penjimatan Air di Institusi Pengajian Tinggi Awam di Negeri Selangor," Penerbit UKM Bangi, Universiti Kebangsaan Malaysia, 2013.

[13] P.A. Cohen, "Using student ratings feedback for improving college instruction: A meta-analysis of findings," Research in Higher Education, vol 13, pp 321-341, 1980.

[14] O. NorAsmah, "Assessing construct validity and reliability of competitiveness scale using Rasch model approach," The 2014 WEI Intenational Academic Conference Proceeding, pp 113-120, 2014.

[15] N.C. Musa et al, "Application of Rasch Measurement Model in Validation and Analysis of Measurement Instruments in Statistical Education Research," Recent Researches in Education, pp 123-129, 2011.

[16] S. T. Cooper et al, "Evaluation of a Perceived Organisational Performance Scale Using Rasch Model Analysis," Australian Journal of Management, Vol 37 No 3, pp 507-522, 2011.

[17] W. Fisher, "Rating Scale Instrument Quality Criteria," Rasch Measurement Transactions, vol 21 No 1, pp 1095, 2007.

[18] T. Bond and C.Fox, "Applying The Rasch Model: Fundamental Measurement In The Human Sciences," Mahwah, Lawrence Erlbaum Associates, NJ, 2007.

[19] J. Jasmi et al, "Online Testing - The Construction of A Functional Model in Assessing Students' Performance Using The Pedagogy of Bloom's Taxonomy," Proceeding Seminar e-Pembelajaran Kebangsaan 2004, 2004.

[20] H. Frank et al, "Student evaluations of teaching: improving teaching quality in higher education, Perspectives: Policy and Practice in Higher Education", vol 21 No 1, pp 26-33, 2016.

[21] P. Seldin, Current practices - good and bad nationally. In P. Seldin \&Associates (Eds.). Changing practices in Evaluating Teaching: A practical guide to improve faculty performance and promotion/tenure decisions. Bolton, MA: Anker, pp. 1-24, 1999.

[22] SRM.Dawam et al., "The use of ICT in public and private institutions of higher learning," Malaysia, Journal of Computer and Information Science, vol 2 No 4, pp 122, 2015. 
[23] HA. Hornstein \& F.Hau, "Student evaluations of teaching are an inadequate assessment tool for evaluating faculty performance," Cogent Education, Vol 4 No 1, DOI: 10.1080/2331186X.2017.1304016, 2017.

[24] L. Jennifer, "Formative Evaluations in Online Classes," The Journal of Educators Online-JEO, vol 13 No 1, pp 1-24, 2016.

[25] A. Norkhushaini and Y.Mohamad, "Evaluation of an Open Source Learning Management System: Claroline," Procedia - Social and Behavioral Sciences, vol 67, pp 416-426, 2012.

\section{BIOGRAPHIES OF AUTHORS}

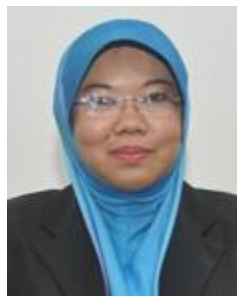

Nor Hapiza Mohd Ariffin Senior Lecturer in Information System Department at Faculty of Computer and Mathematical Sciences in Universiti Teknnologi Mara, Selangor, Malaysia. Hold a Bachelor in Computer Science (Hons) in 1994, Masters in Information Technology in 2001 and $\mathrm{PhD}$ in System and Science Management in 2010 from Universiti Kebangsaan Malaysia. She is being recognised by Malaysia Board of Technologist (MBOT) as Profesional Technologist (TS).

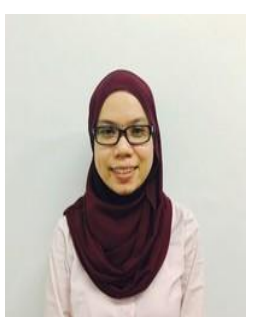

Siti Nor Hidayah Askol Experienced System Engineer with a demonstrated history of working in the information technology and services industry. Skilled in Windows Server, Microsoft Excel, Microsoft Word, VMware and Hyperconverged technology. Hold a Bachelor in Information Technology in 2015 from Universiti Teknologi Mara Malaysia. 